\title{
POTENTIAL RESISTANCE OF OKRA LEAF Bt COTTON AGAINST INSECT PESTS
}

\author{
NAZIR, M. S. ${ }^{*}-$ MALIK, T. A. ${ }^{1}-$ SHAKEEL, A. ${ }^{1}-$ AHMAD, J. N. ${ }^{2}$ \\ ${ }^{I}$ Department of Plant Breeding and Genetics, University of Agriculture, Faisalabad, Punjab, \\ Pakistan \\ ${ }^{2}$ Department of Entomology, University of Agriculture Faisalabad Punjab, Pakistan \\ *Corresponding author \\ e-mail: 2008ag2267@uaf.edu.pk \\ (Received $9^{\text {th }}$ Dec 2018; accepted $28^{\text {th }}$ Feb 2019)
}

\begin{abstract}
Cotton with Bt gene is only resistant against bollworms. Sucking insect pests also cause huge losses to cotton crop. It is reported that okra leaf cotton genotypes are resistant to sucking insect pests. The objective of this research was to explore the potential of okra leaf Bt cotton for resistance against bollworms and sucking insect pests. Okra leaf Bt cotton recombinant lines were developed by hybridization and selection process for use in this study. Comparative insect pest buildup/infestation was studied on non $\mathrm{Bt}$ normal leaf, normal leaf $\mathrm{Bt}$, non $\mathrm{Bt}$ okra leaf and okra leaf $\mathrm{Bt}$ genotypes/cultivars/recombinant lines under field conditions using randomized complete block design with three replications. The genotypes/cultivars/recombinant lines were separated by nets to confined the insect population buildup within the genotype. Significantly lower buildup of sucking insect pests was found on okra leaf cotton compared to normal leaf cotton and significantly lower buildup/infestation of sucking insects as well bollworms was found on okra leaf recombinant lines with Bt gene. Development of Bt cultivars with okra leaf is recommended which would be resistant against bollworms as well as sucking insect pests attacks.
\end{abstract}

Keywords: sucking insects, bollworms, okra leaf, normal leaf, Bt cotton

\section{Introduction}

Pakistan is the $4^{\text {th }}$ largest producer of cotton in the world. Cotton crop is severely damaged by many sucking insects (Jassid, whitefly, aphid, thrips) and bollworms (American bollworm, Spotted bollworm and Pink bollworm). Genetically modified Bt cotton is only resistant to bollworms but is not resistant to sucking insect pests (Din et al., 2016). Huge quantity of insecticide is applied to protect Bt cotton from sucking insect pests which increases production cost of cotton crop and pollute the environment. So, Bt cotton cultivars which may be resistant to sucking insect pests as well may be developed.

It has been reported that population buildup of sucking insect pests on cotton with okra leaf trait is comparatively low due to its open canopy (Chu et al., 2000; Soomro et al., 2000; Ahmad et al., 2005; Din et al., 2016). The objective of present research was to explore the potential of $\mathrm{Bt}$ cotton with okra leaf trait for resistance against sucking insect pests and bollworms.

Assessment of cotton against insect pests by scoring insect pest population buildup on genotype under field conditions is tedious work as the experimental plots of the genotypes have to be separated by nets to confine the insect population within the genotype. Thus, only a small number of such studies are found in the literature. The present study was conducted to assess the comparative insect pest buildup/infestation on okra leaf (non Bt and Bt) and normal leaf (non Bt and Bt) cotton under field condition. 


\section{Material and methods}

The study was conducted in the field area of the University of Agriculture Faisalabad (Latitude $=31^{\circ} 26^{\prime} \mathrm{N}$, Longitude $=73^{\circ} 06^{\prime} \mathrm{E}$, Altitude $\left.=184.4 \mathrm{~m}\right)$, Pakistan, during the year 2014 to 2016 . Faisalabad possess the arid climate. It can touch both extremes, with a summer with maximum temperature $50^{\circ} \mathrm{C}$ and winter temperature of $-2{ }^{\circ} \mathrm{C}$.

\section{Development of okra leaf Bt cotton recombinant lines}

In year 2014 crosses were made and $\mathrm{F}_{1}$ generation was developed ((MNH$886 \times$ Gumbo Okra), (CRS-456 $\times$ Gumbo Okra) and (PB-38 $\times$ Gumbo Okra)), in season $2015 F_{1}$ were sown and $F_{2}$ was raised into the field. Recombinant okra leaf Bt cotton lines were selected from the $\mathrm{F}_{2}$ populations of the cross of Gumbo okra (okra leaf) with normal leaf genotypes/cultivars. Recombinant plants from $\mathrm{F}_{2}$ were selected on the basis of okra leaves with high yielding traits and Bt proteins test by using ELISA (QualiPlate $^{\mathrm{TM}}$ Kit for Cry1Ab/Cry1Ac by Enviro-Logics). The Enviro-Logix QualiPlate Kit is a "sandwich Enzyme-Linked Immuno Sorbent Assay" (ELISA). List of cotton genotypes/cultivars/recombinant lines used in the study is given in Table 1.

To assess the comparative insect pest buildup/infestation, Eight G. hirsutum genotypes/cultivars/recombinant lines were sown at the $27^{\text {th }}$ of March (2016) under normal soil and irrigation conditions in randomized complete block design with three replications. Standard agronomic practices of growing cotton crop were used in the experiment. There were 24 rows, each $300 \mathrm{~cm}$ in length (10 plant in each row) in each replication (three rows for each genotype/cultivar/ recombinant line) by keeping the plant to plant distance of $30 \mathrm{~cm}$ and row to row distance of $75 \mathrm{~cm}$.

Table 1. List of cotton genotypes/cultivars/recombinant lines evaluated for resistance against different insect pests under field condition

\begin{tabular}{c|c|c}
\hline Sr. No. & Genotype/cultivar & Description \\
\hline 1. & PB-38 & Cultivar with Normal leaf trait \\
2. & MNH-886 & Cultivar with Normal leaf trait + Cry1Ac \\
3. & FH-142 & Cultivar with Normal leaf trait + Cry1Ac \\
4. & FH-lalazar & Cultivar with Normal leaf trait + Cry1Ac \\
5. & Gumbo Okra & Genotype with Okra leaf trait \\
6. & $\mathrm{RP}_{1}(\mathrm{MNH}-886 \times$ Gumbo Okra) & Recombinant population with Okra leaf + Cry1Ac \\
7. & $\mathrm{RP}_{2}(\mathrm{CRS}-456 \times$ Gumbo Okra $)$ & Recombinant population with Okra leaf + Cry1Ac \\
8. & $\mathrm{RP}_{3}(\mathrm{~PB}-38 \times$ Gumbo Okra $)$ & Recombinant population with Okra leaf trait \\
\hline
\end{tabular}

The data were taken at ten-day intervals beginning from $15^{\text {th }}$ of May 2016 to $15^{\text {th }}$ of November 2016 from ten healthy plants randomly selected from each genotype/cultivar/recombinant line. For sucking insects (thrips, jassid, aphid, whitefly and mites), from each plant three leaves were selected (one each from top, middle and bottom) and examined for both adult and nymph, using magnifying glass. The population of bollworms (Pink bollworm, Spotted bollworm, and American bollworm) were assessed by counting infested bolls, squares and flowers on per plant basis. Analysis of variance of insect pest's data was conducted and means were separated by LSD test as in Steel et al. (1997). 


\section{Results}

The population means of insect pest buildup/infestation (Pink bollworm, American bollworm, thrips, jassid, whitefly, mites, aphid) on different genotypes/cultivars/recombinant lines are given in Table 2. The analysis of variance showed significant variation for insect pest population built up on different genotypes/cultivars/recombinant lines. Comparison of means of insect pests buildup/infestation of (Pink bollworm, American bollworm, thrips, jassid, whitefly, mites, aphid) on different genotypes/cultivars/ recombinant lines by using LSD test is also given in Table 2. The results showed that Gossypium hirsutum genotypes/cultivars with normal leaf trait had significantly higher thrips population buildup comparatively to the okra leaf genotypes/recombinant lines. Maximum infestation was found on FHlalazar which is a normal leaf variety while minimum infestation was found on okra leaf line $\mathrm{RP}_{2}$. Maximum number of Jassid population was found on $\mathrm{FH}$-lalazar followed by other normal leaf cultivars while minimum number of infestations was found on okra leaf line $\mathrm{RP}_{2}$. Results showed that comparative population built up of whitefly was significantly higher on normal leaf genotypes/cultivars as compared to okra leaf genotype/cultivar/ line.

Table 2. Mean population buildup/infestation of insect pests on cotton genotypes/cultivars/recombinant lines

\begin{tabular}{c|c|c|c|c|c|c|c|c}
\hline Insects & Thrip & Jassid & Whitefly & Aphid & Mites & $\begin{array}{c}\text { Spotted } \\
\text { bollworm }\end{array}$ & $\begin{array}{c}\text { Pink } \\
\text { bollworm }\end{array}$ & $\begin{array}{c}\text { American } \\
\text { bollworm }\end{array}$ \\
\hline Penotypes & $5.273 \mathrm{~b}$ & $4.410 \mathrm{c}$ & $8.420 \mathrm{~b}$ & $8.333 \mathrm{a}$ & $7.563 \mathrm{~b}$ & $10.037 \mathrm{a}$ & $9.553 \mathrm{a}$ & $11.070 \mathrm{a}$ \\
MNH-886 & $5.204 \mathrm{~b}$ & $4.589 \mathrm{c}$ & $8.306 \mathrm{~b}$ & $9.016 \mathrm{a}$ & $8.261 \mathrm{a}$ & $0.291 \mathrm{~cd}$ & $1.078 \mathrm{~cd}$ & $0.411 \mathrm{~d}$ \\
FH-142 & $5.728 \mathrm{a}$ & $5.076 \mathrm{~b}$ & $8.816 \mathrm{a}$ & $8.551 \mathrm{a}$ & $8.116 \mathrm{a}$ & $0.744 \mathrm{c}$ & $202 \mathrm{c}$ & $0.869 \mathrm{~d}$ \\
FH-lalazar & $5.941 \mathrm{a}$ & $5.559 \mathrm{a}$ & $7.309 \mathrm{c}$ & $8.861 \mathrm{a}$ & $7.414 \mathrm{~b}$ & $0.478 \mathrm{~cd}$ & $1.154 \mathrm{~cd}$ & $0.620 \mathrm{~d}$ \\
Gumbo Okra & $4.498 \mathrm{c}$ & $2.411 \mathrm{~d}$ & $3.287 \mathrm{~d}$ & $4.431 \mathrm{bc}$ & $5.187 \mathrm{e}$ & $4.096 \mathrm{~b}$ & $6.341 \mathrm{~b}$ & $4.341 \mathrm{~b}$ \\
$\mathrm{RP}_{1}$ & $3.519 \mathrm{~d}$ & $2.485 \mathrm{de}$ & $2.780 \mathrm{e}$ & $3.764 \mathrm{~cd}$ & $6.094 \mathrm{c}$ & $0.044 \mathrm{~d}$ & $0.026 \mathrm{~d}$ & $0.298 \mathrm{e}$ \\
$\mathrm{RP}_{2}$ & $3.413 \mathrm{~d}$ & $1.887 \mathrm{e}$ & $3.022 \mathrm{de}$ & $3.570 \mathrm{~d}$ & $5.568 \mathrm{~d}$ & $0.119 \mathrm{~cd}$ & $0.053 \mathrm{~cd}$ & $0.199 \mathrm{e}$ \\
$\mathrm{RP}_{3}$ & $4.728 \mathrm{c}$ & $2.693 \mathrm{~d}$ & $3.254 \mathrm{~d}$ & $4.707 \mathrm{~b}$ & $5.922 \mathrm{c}$ & $4.641 \mathrm{~b}$ & $5.294 \mathrm{~b}$ & $3.84 \mathrm{c}$ \\
\hline MS for genotype & $2.661 * *$ & $6.022^{* *}$ & $23.131 * *$ & $18.413 * *$ & $4.374 * *$ & $44.356 * *$ & $65.528 * *$ & $77.423 * *$ \\
LSD value & 0.399 & 0.342 & 0.340 & 0.780 & 0.242 & 0.638 & 0.399 & 0.486 \\
\hline
\end{tabular}

**Highly significant $(\mathrm{p}<0.01)$

*Significant $(\mathrm{p}<0.05)$

Genotypes/cultivars/recombinant lines not sharing the same letter are significantly different

Maximum number of whiteflies was found on normal leaf cultivar FH-142 followed by other normal leaf genotype/cultivar PB-38 and MNH-886. Minimum number of whiteflies were found on okra leaf line $\mathrm{RP}_{1}$. Results showed that comparative population built up of whitefly was significantly higher on normal leaf genotypes/cultivars as compared to okra leaf genotype/cultivar/ recombinant line. Maximum number of whiteflies was found on normal leaf cultivar FH-142 followed by other normal leaf genotype/cultivar PB-38 and MNH-886. Minimum number of whiteflies was found on okra leaf line $\mathrm{RP}_{1}$. Comparatively high infestation of mites was found on normal leaf genotypes/cultivars as compared to okra leaf genotypes/cultivars/ recombinant lines. Maximum number of mites population was found on MNH-886 and FH-142 while minimum number of infestation was found at Gumbo okra followed by other okra leaf genotype/ recombinant lines. Overall results showed that normal leaf cotton (PB-38, MNH-886, FH-142 and FH-lalazar) had high buildup of sucking insect 
pests compared to okra leaf cotton (Gumbo Okra, $\mathrm{RP}_{1}, \mathrm{RP}_{2}$ and $\mathrm{RP}_{3}$ ). Significantly higher infestation of bollworms was found on non Bt cotton (PB-38, Gumbo Okra, and $\mathrm{RP}_{3}$ ) compared to Bt cotton (MNH-886, FH-142, FH-lalazar $\mathrm{RP}_{1}$ and $\left.\mathrm{RP}_{2}\right)$. Non Bt okra leaf Cotton (Gumbo Okra, and $\mathrm{RP}_{3}$ ) had lower infestation compared to normal leaf non Bt cotton (PB-38).

\section{Discussion}

Okra leaf trait is characterized by narrowly lobbed and deeply cleft leaves with less per leaf surface area compared to normal leaf cotton. It has been reported that okra leaf cotton is resistant to sucking insect pests and also relatively resistant to bollworms compared to normal leaf cotton. In the present study and in earlier reports lower buildup of sucking insect on okra leaf cotton compared to normal leaf cotton was due to its reduced leaf surface area and open canopy (Kular and Butter, 1999; Arif et al., 2006; Din et al., 2016). In a study of eight cotton cultivars from USA and six from Australia, Chu et al. (1999) observed that okra leaf cotton cultivars had lower attack of whitefly compared to normal leaf cotton cultivars. It was suggested that okra leaf trait had great potential for breeding upland cotton resistant to whitefly. Kanher et al. (2016) reported positive correlation of leaf area and aphid population on cotton. So, development of okra leaf cultivars has been suggested to control sucking insect pests (Wilson, 1994; Soomro et al., 2000; Chu et al., 2002; Ahmad et al., 2005; Din et al., 2016; Kanher et al., 2016). Wilson (1889) observed that okra leaf cotton required 33\% less insecticide and had less damage by insect pests but yield was as much as normal leaf cultivars. Smith (2001) also compared okra leaf cotton with normal leaf cotton and found that okra leaf cotton was equal in fiber length, fiber strength and fiber fineness as well as yield. Wilson and George (1982) found that okra leaf cultivars were resistant to bollworms compared to the normal leaf cultivars. They concluded that okra leaf cultivars had smaller leaf area and open plant canopy leading to better light penetration and more air circulation which made these cultivars resistant to bollworms. Din et al. (2016) also found in a field study that okra leaf cotton was resistant to bollworms.

Okra leaf trait in cotton is controlled by single gene. Its locus has been reported on chromosome 15 on D genome (Andres et al., 2016). Okra leaf trait is monogenic in inheritance so, breeding cultivars with okra leaf trait may not be difficult. Results of present study and earlier findings suggest that okra leaf cotton Bt cultivars should be tailored to control sucking insect pests and bollworms.

\section{Conclusion}

Findings of this study revealed significantly lower buildup/infestation of bollworms (pink bollworm, American bollworm, spotted bollworm) and sucking insects (Aphid, Jassid, Whitefly, thrips and whitefly) on okra leaf Bt cotton compared to normal leaf Bt cotton. So, Bt cotton cultivars with okra leaf trait should be engineered which would be resistant to bollworms as well as sucking insect pests.

\section{REFERENCES}

[1] Abro, G. H., Syed, T. S., Dayo. Z. A. (2003): Varietal resistance of cotton against Earias Spp. - Pakistan Journal of Biological Sciences 6: 1837-1839. 
[2] Ahmad, G., Arif, M. J., Ramzan, M., Sanpal, Z. (2005): Population fluctuation of jassid (Amrasca devastans) in cotton through morphological plant traits. - Caderno de pesquisa. Série Biologia 17: 71-79.

[3] Andres, R. J., Coneva, V., Frank, M. H., Tuttle, J. R., Samayoa, L. F., Han, S. W., Kaur, B., Zhu, L., Fang, H., Bowman, D. T., Rojas-Pierce, M. (2016): Modifications to a LATE MERISTEM IDENTITY1 gene are responsible for the major leaf shapes of Upland cotton (Gossypium hirsutum L.). - Proceedings of the National Academy of Sciences 114: 57-66.

[4] Arif, M. J., Gogi, M. D., Ahmad, G. (2006): Role of morpho-physical plant factors imparting resistance in cotton against thrips. - Arab Journal of Plant Protection 24: 57-60.

[5] Chu, C. C., Cohen, A. C., Natwick, E. T., Simmons, G. S., Henneberry, T. J. (1999): Bemisia tabaci (Hemiptera: Aleyrodidae) biotype B colonization and leaf morphology relationships in upland cotton cultivars. - Australian Journal of Entomology 38: 127-131.

[6] Chu, C. C., Natwick, E. T., Henneberry, T. J., Duggar, P., Richter, R. (2000): Susceptibility of normal leaf and okra leaf shape cotton to silver leaf whitefly and relationships to trichome densities. - Proceedings, Beltwide Cotton Conferences, 4-8 January, San Antonica, USA.

[7] Chu, C. C., Natwick, E. T., Hennerberry, T. J. (2002): Bemisia tabaci biotype B colonization on okra and normal leaf upland cotton strains and cultivars. - Journal of Economic Entomology 95: 733-738.

[8] Din, Z. M., Malik, T. A., Azhar, F. M., Ashraf, M. (2016): Natural resistance against insect pests in cotton. - Journal of Animal and Plant Science 25: 1346-1353.

[9] Kanher, F. M., Syed, T. S., Abro, G. H., Jahangir, T. M. (2016): Effect of cotton leaf morphological characters on incidence of Amrasca Devastans. - Sindh University Research Journal 48: 271-280.

[10] Kular, J. S., Butter, N. S. 1999. Influence of some morphological trait of cotton genotypes on resistance to whitefly, Bemisia tabaci. - Journal of Insect Science 12: 81-83.

[11] Smith, C. W. (2001): Registration of three morphological variant upland cotton germplasm lines. - Crop Science 41: 1371-1372.

[12] Soomro, A. R., Soomro, A. W., Mallah, G. H., Memon, A. M., Soomro, A. H. (2000): Okra leaf cotton, its commercial utilization in Sindh. - Pakistan Journal of Biological Sciences 3: 188-190.

[13] Steel, R. G. D., Torrie, J. H., Dickey, D. A. (1997): Principles and Procedures of Statistics: A Biometrical Approach. 3rd. Ed. - McGraw Hill Book Co. Inc, New York, pp. 400-428.

[14] Wilson, F. D. (1989): Yeild, earliness and fiber properties cotton carrying combined traits for pink bollworm resistance. - Crop Science 29: 7-12.

[15] Wilson, F. D., George, B. W. (1982): Effects of okra leaf, frego bract, and smooth leaf mutants on pink boll worm damage and agronomic properties of cotton. - Crop Science 22: 798-801.

[16] Wilson, L. J. (1994): Resistance of okra leaf cotton to two spotted spider mites. - Journal of Economic Entomology 87: 1726-1735. 